\title{
Water Collection from Air Humidity in Bahrain
}

\author{
Nidal A. Dahman. Khalil J. Al Juboori, Eman A. BuKamal, Fatima M. Ali, \\ Khadija K., AlSharooqi, and Shaima A. Al-Banna.
}

\author{
Civil Engineering Department, University of Bahrain, Isa Town, Kingdom of Bahrain \\ ndahman@uob.edu.bh,kaljuboori@uob.edu.bh,emanz1994@gmail.com, \\ Fatima.mousa8@gmail.com, Khadija.alshurooqi2@gmail.com , \\ Shaima.albanna.11@gmail.com
}

\begin{abstract}
The Kingdom of Bahrain falls geographically in one of the driest regions in the world. Conventional fresh surface water bodies, such as rivers and lakes, are nonexistent and for water consumption, Bahrain prominently relies on the desalination of sea water. This paper presents an ongoing project that is being pursued by a group of student and their advising professors to investigate the viability of extracting water from air humidity. Dehumidifiers have been utilized as water extraction devices. Those devices have been distributed on six areas that were selected based on a rigorous geospatial modeling of historical meteorological data. The areas fall in residential and industrial neighborhoods that are located in the main island and the island of Muharraq. Water samples have been collected three times every week since May of 2016 and the collection process will continue until May of 2017. The collected water samples have been analyzed against numerous variables individually and in combinations including: amount of water collected per hour versus geographical location, amount of water collected per hour versus meteorological factors, suitability of collected water for potable human consumption, detection of air pollution in the areas of collection and the economy of this method of water collection in comparison to other nonconventional methods. An overview of the completed analysis results is presented in this paper.
\end{abstract}

Keywords: Bahrain, GIS, Renewable Projects and Applications, Sustainable Water Supply, Multi criteria modeling.

\section{Introduction}

It is a common knowledge that planet Earth's atmosphere is composed mainly of gases such as nitrogen, oxygen and carbon dioxide. The lower altitude of the atmosphere, called the troposphere, also contains quantities of water in its gaseous form of vapor. Quantities of water vapor in the troposphere near the earth surface span from a negligible $0.01 \%$ to about $4.25 \%$ of air volume [2]. Therefore, on average, about $2.1 \%$ of the air we breathe is water. The geography, climate and 
closeness to significant water bodies determine how moist or dry the atmosphere of an area is. By mass and volume, atmospheric moisture ranges from zero grams per cubic meter in dry air to more than 50 grams per cubic meter, when the air is saturated with water vapor at $40^{\circ} \mathrm{C}$ (Figure 1) $[16,17]$. Considering that an average of $2 \%$ of the troposphere is made of water vapor, a simple calculation of the troposphere volume multiplied by 0.02 reveals that earth's troposphere contains close to $1.42 \times 10^{7}$ cubic kilometers of water, in its gaseous vapor form. This astounding amount of pure water can be harvested for various uses of humanity via passive and active means.

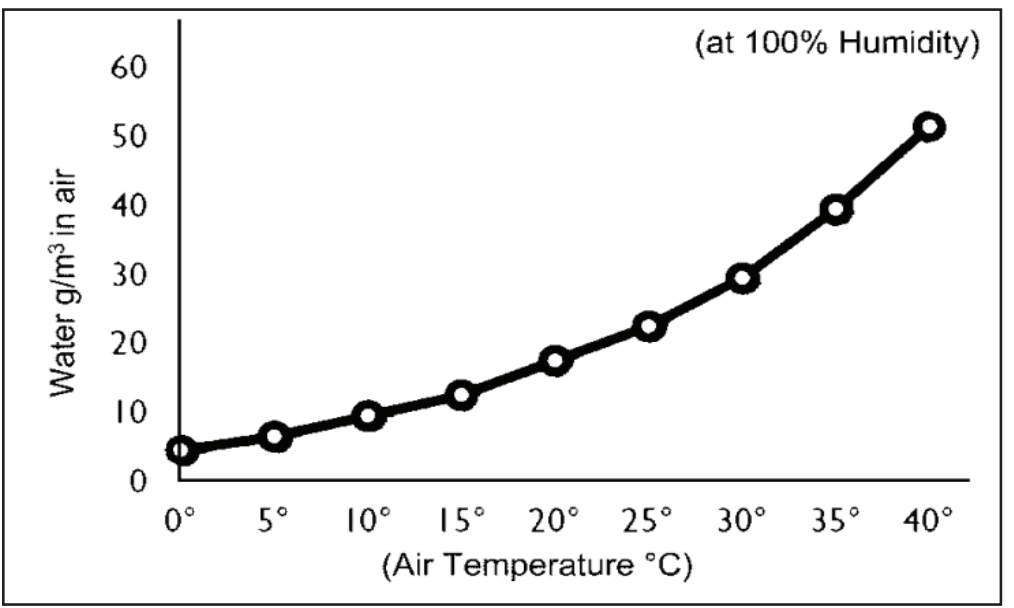

Figure 1: Saturation Atmospheric Moisture Content at Different Temperatures. [After Ref. 2]

The kingdom of Bahrain is an archipelago in the Arabian Gulf. It geographically falls in UTM 39R, at a latitude and longitude of $26^{\circ} 1^{\prime} 39^{\prime \prime} \mathrm{N}$ and $50^{\circ} 33^{\prime} 0^{\prime \prime} \mathrm{E}$ respectively. These geographical coordinates place Bahrain in a very arid region, where the daily average high temperature is in excess of $26^{\circ} \mathrm{C}$ and the average yearly precipitation is less than $25 \mathrm{~mm}$. Moreover, being an island-nation makes the weather humid all year long with an average low relative humidity of $47 \%$ and an average high relative humidity of $83 \%$. Figure 2 presents the monthly averages of temperature, humidity and dew point for the Kingdom of Bahrain the last 5 years. This figure was produced from a data that was obtained from Meteorological Directorate Climate \& Observation section of the Bahrain Ministry of Transportation and Telecommunications [13]. 


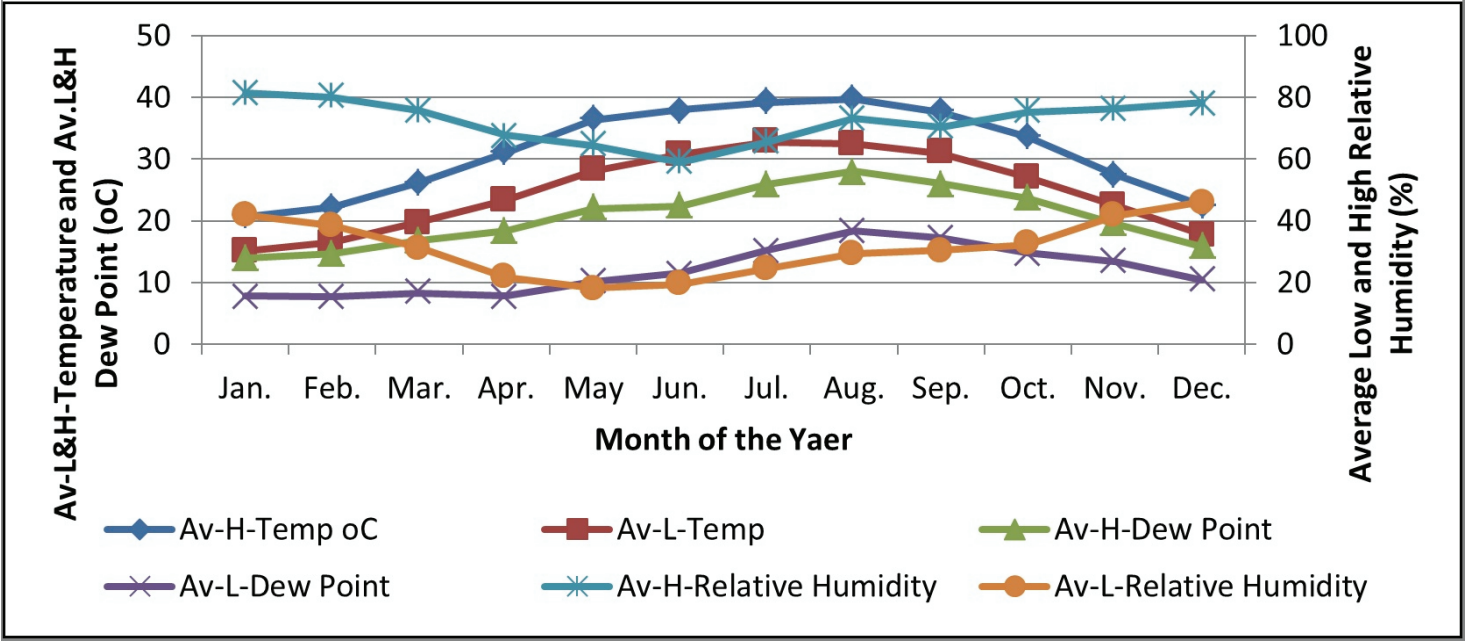

Figure 2: Average Weather Elements of Bahrain based on the last 5-year data.

This paper presents an ongoing project that is pursued at the civil engineering department of the University of Bahrain to investigate the viability of extracting water from air humidity and outlines the results that have been achieved thus far. The project involves many facets and goals, including the quantities of water that can be collected versus geographical locations and meteorological factors, suitability of the collected water for human consumption, detection of air pollution in the collection areas and the economy of this method in comparison with desalination of sea water.

The next section of this paper presents a brief background from meteorology and engineering. Thereafter, a quick literature review is followed by research methodology, analysis of results and finally, conclusions and recommendations for further studies.

\section{Background}

The water vapor content of air in a certain location is referred to as humidity and there are numerous ways to measure it, including among others: absolute humidity, specific humidity, mixing ratio, relative humidity and dew point. [2]

Absolute humidity (AH) is the mass of water vapor existing in a unit volume of air and is expressed in grams per cubic meter. Specific humidity $(\mathrm{SH})$ is the ratio of water vapor mass to the total mass of an air parcel (dry air plus water vapor). An alternative term is the Mixing Ratio (MR), which indicates the ratio of the mass of water vapor in a given volume of air to the mass of dry air in the same volume. 
Relative humidity $(\mathrm{RH})$ is the ratio of the current moisture content of a unit volume of air to its saturation moisture content at the same temperature and pressure and is expressed as a percentage. RH can't exceed $100 \%$ and it is the measure used by meteorologists in their forecasts of rain, dew or fog. Dew point (DP) is the temperature at which $\mathrm{RH}$ reaches $100 \%$. At that point, if more vapor is induced, air humidity is relinquished as liquid water. The amount of humidity that air can tolerate depends on temperature as warmer air can bear more vapor than cold air. [2]. For the sake of this research, $\mathrm{AH}$ is more straightforward to apply, but all meteorological data obtained from authorities is expressed in $\mathrm{RH}$ terms. AH can be computed from $\mathrm{RH}$ at a given temperature using the following famous Equation (1). This equation was used to produce the curve in Figure 1 and it is based on the physics of ideal gases [11].

$A H\left(\frac{g m}{m^{3}}\right)=\frac{6.112 \times e^{\left[\frac{17.67 \times T}{T+243.5}\right]} \times R H \times 2.1674}{273.15+T}$

\section{1- Previous Works Investigation}

Atmospheric water can be harvested by passive methods or active methods. Passive methods are suitable for atmospheric humidity that has already condensed to liquid rain, dew or fog. They just collect naturally-condensed water droplets from wet air and stream them into collection tanks. For many centuries people of arid and semi-arid regions have collected winter rain flowing down from building roofs and stored it in tanks and land pits for later human, animal and agricultural consumption [9]. A more recent passive method of atmospheric moisture collection utilizes screens and meshes to hunt dew mist and fog droplets and deposit them into gutters that stream them into collection tanks $[3,12,15,24]$. A third method of passive atmospheric water harvesting involves chemical treatment of cotton fabrics to enable them to absorb considerable amounts of water from misty air that can be more than three times of their own weights [27]. 


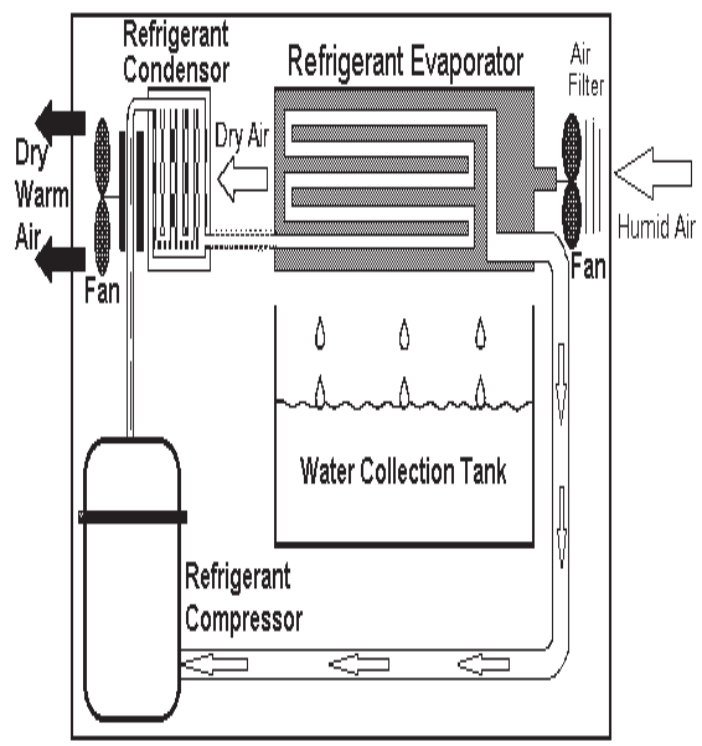

Figure 3: The Architecture of an Active Atmospheric Water Harvesting Device.

Active harvesting of atmospheric humidity requires special dehumidifiers that condense atmospheric moisture to produce liquid water. Electromechanical/refrigerative dehumidifiers come with refrigerative coils, where moist atmospheric air is forced to pass through the cold coils. This causes the condensation of gaseous vapor into liquid water. This water is then streamed into collection tanks as shown in Figure $3[7,10,16]$. In the last few years these active methods of harvesting atmospheric moisture have been researched extensively. Numerous research papers have been published $[1,4,5,19]$ and the research has traversed in many directions including: new harvesting methods and equipment $[6,8,14,21,22]$, improving the efficiency of existing hardware $[18,20,25]$ and examining the viability of these methods to geographic locales $[17,24]$.



Figure 4: Over-the-Shelf Dehumidifier. 


\section{2- Methodology}

For the purpose of this project, six of over-the-shelf dehumidifiers, shown in Figure 4, were utilized as air-humidity water-harvesting devices. According to the manufacturer's sticker on the rear side, the device has a rated voltage of 220-240 Volts of alternative current at $50 \mathrm{~Hz}$ frequency, an input power of $330 \mathrm{Watts}$, and a rated current of 1.5 Amperes. According to the manufacturer, the device is capable of extracting up to 20 liters of water per day at $30^{\circ} \mathrm{C}$ and $80 \% \mathrm{RH}$ by processing 180 $\mathrm{m}^{3}$ of air per hour with a suction pressure of $0.5 \mathrm{MPa}$ and discharge fan pressure of 1.5 $\mathrm{MPa}$. The devices were acquired from a local department store and installed in six cities of the kingdom of Bahrain as shown in Figure 5. A merger of Geographic Information Systems (GIS) and meteorological data tables assisted the selection of the locations of the water collection devices [13]. The six devices were placed in six geographical locations that cover diverse characteristics, such as closeness to shores land-use classification (residential versus industrial). Those locations are: Hidd, Manama, Barbar, Salmabad, Sanad and Hamad Town. The first city is in the island of Muharraq, while the later five are in located the main island. The experiment of water collection, using these devices, started on May of 2016 and will continue until May of 2017. The devices are operated by third to $6^{\text {th }}$ coauthors of this paper for one hour every time, three times a week with three different starting and ending collection times that cover early morning (6:00 to 7:00 AM), mid-day (1:00 to 2:00 PM) and evening (8:00 to 9:00PM). By the end of each operation session, the amount of harvested raw water is measured and logged into a spreadsheet along with other concurrent meteorological data, such as weather status, relative humidity, temperature, wind direction and due point.

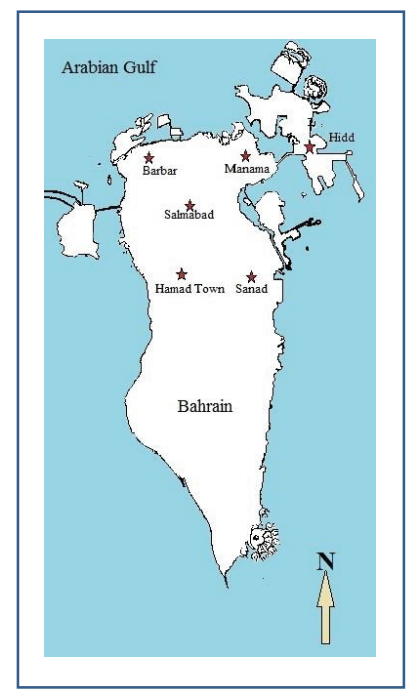

Figure 5: Locations of the water collection devices in the Kingdom of Bahrain. 
By design, harvested water samples do not undergo any filtration and are kept raw. In theory, the water harvested from atmospheric humidity should be pure and distilled, but without any filtration, it is fair to expect it to contain many air-borne ingredients such as, dust particles, pollen, mold spores and bacteria. Identifying those ingredients can provide researchers with a plethora of environmental air quality indicators about the air pollutants in the water collection sites.

To calculate the efficiency of the harvesting device, the following general expression of efficiency can be adopted;

$$
\eta=\frac{\text { Process Output }}{\text { Process Input }} X 100 \%
$$

Equation (2) can be tailored for the utilized harvesting device as follows:

$$
\eta=\frac{\text { Volume of Water Harvested per Unit Time }}{(\text { Total Volume of Air Processed per Unit Time) X(AH) }} X 100 \%
$$

Then, the per-unit-time capacity $(C)$ of the harvesting device in liters can be expressed as:

$$
C=\operatorname{Airflow}\left(\mathrm{m}^{3} / \mathrm{hr}\right) X A H\left(\mathrm{gm} / \mathrm{m}^{3}\right) X 0.001(\mathrm{~L} / \mathrm{gm}) X \eta
$$

\section{3- Results and Analysis}

For the sake of this paper, a representative sample of the harvested waters from each of the six collection sites was tested in the civil engineering instructional laboratories for acidity/basicity ( $\mathrm{pH}$ value), electric conductivity, total dissolved solids, and the dissolved ions of nitrates that are detectable by the accessible spectrometer. In addition, a bacteria count test was performed on freshly-collected samples, and to the authors' surprise, the number of colonies was zero in $100 \mathrm{ml}$. The results are presented in the following Table 1. 
Table 1: Preliminary Chemical Analysis Results on Some Harvested Water Samples.

\begin{tabular}{|l|l|l|l|l|}
\hline $\begin{array}{l}\text { Sample } \\
\text { Origin }\end{array}$ & $\mathbf{p H}$ & $\begin{array}{l}\text { Conductivity } \\
(\boldsymbol{\mu S} / \mathbf{m})\end{array}$ & $\begin{array}{l}\text { Nitrate } \\
(\mathbf{m g} / \mathbf{l})\end{array}$ & $\begin{array}{l}\text { TSS } \\
(\mathbf{m g} / \mathbf{l})\end{array}$ \\
\hline BarBar & 7.1 & 83 & 35.8 & $2 \times 10^{-4}$ \\
\hline Manama & 7.0 & 50 & 31.2 & $5.4 \times 10^{-4}$ \\
\hline Hidd & 7.0 & 46 & 35.8 & 0.00 \\
\hline Salmabad & 6.9 & 44 & 35.8 & $4.1 \times 10^{-4}$ \\
\hline Sanad & 7.0 & 53 & 11.1 & $4.1 \times 10^{-4}$ \\
\hline Hamad Town & 7.0 & 25 & 5.9 & 0.00 \\
\hline
\end{tabular}

The preliminary results shown in Table 1 look very promising and are in agreement of what has been reported in the health literature [26]. Nonetheless, to overcome the limitations of the instructional labs, a set of water samples from each collection site has been sent to the official water labs of the Electricity and Water Authority (EWA) and the official labs of the Ministry of Health for comprehensive chemical, bacteriology tests and pathogen analysis. As of the time of writing this version of this paper, results of those official tests have not been received yet.

In the meantime a look can be taken at the harvested water data. Figure 6 shows the hourly average quantities of harvested waters in each of the six locations. The figure shows that there is more potential to collect more water in Barbar and Hidd because of their closeness to the see in comparison to Hamad Town and Salmabad that are far away from the shores. 


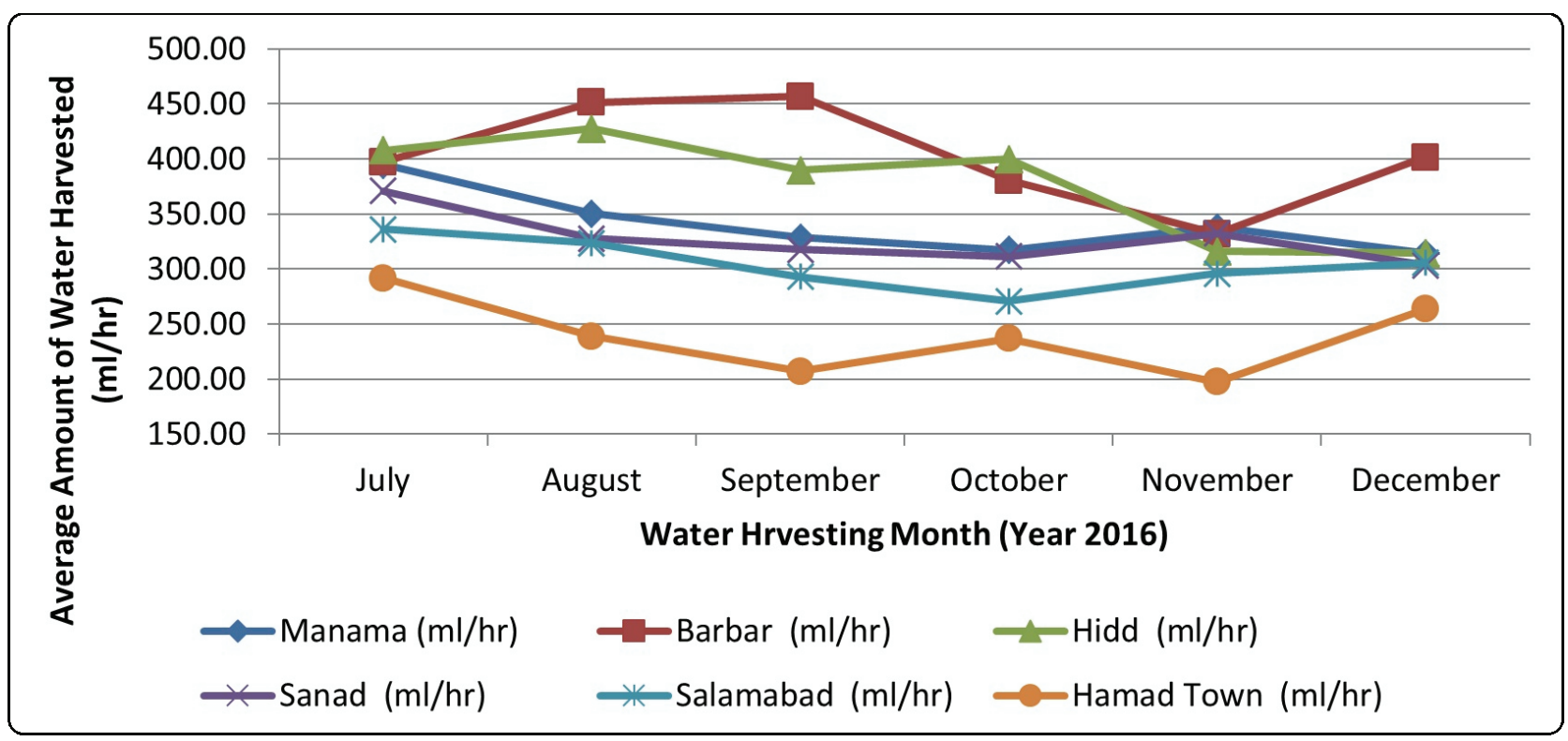

Figure 6: Hourly average quantities of harvested waters in each of the six locations

It was found that for the first six months of operation, the used harvesting devices could produce an average of 332 milliliters of water per hour. Based on this $332 \mathrm{ml}$, and based on the manufacturer's data that the device processes $180 \mathrm{~m}^{3} / \mathrm{hr}$, and with an average daily absolute humidity (AH) of $36.03 \mathrm{gm} / \mathrm{m}^{3}$ that was calculated using Equation (1) from meteorological data provided by Bahrain's Meteorological Authority, the efficiency of used device is:

$\eta=\frac{332.0}{180 X 36.03} X 100 \%=5.12 \%$

The pressing question is how economical is this method? And how much water can be harvested per unit consumption of energy? And how much is the cost per unit volume of harvested waters?

The manufacturer's sticker on the back of the dehumidifier states that the device draws 300 watts of electric power. According to the electricity bill of the first author, the government of Bahrain sells electricity to citizens and residents for 0.003 Bahrain Dinar (BHD) per kilo-watt-hour $(\mathrm{kWh})$. The exchange rate against the American Dollar is BHD $1.00=\$ 2.65$ makes the cost of electricity in Bahrain $\$ 0.008 / \mathrm{kWh}$.

$\rightarrow 300$ watts $\times 1$ hours of operation $=300$ watt-hour per hour of operation

$\rightarrow 300$ watt-hours $\div 1000=0.3 \mathrm{kWh}$

$\rightarrow 0.3 \mathrm{kWh} \times \$ 0.008 / \mathrm{kWh}=\$ 0.0024$ for every hour of operation. 
Given the fact that the harvesting device has been yielding an average of $332.0 \mathrm{ml}$ per hour, the device will cost $\$ 7.23$ of electricity to produce $1.0 \mathrm{~m} 3$ of water. This is in expensive for a device that has only $5.12 \%$ efficiency. This cost can be reduced by a factor of 20 or even more, if a device with a harvesting efficiency of $80 \%$ or more is used, which puts it in a real competition with other nonconventional potable water production methods like desalination.

Finally, Data of the average quantities of water that could be harvested in each of the six collection locations over the first six months of the experiment, time of the year, average temperature, average relative humidity, average absolute humidity, and the average dew point are presented in Table 2.

Table 2: Harvested waters per month with associated meteorological factors

\begin{tabular}{|c|c|c|c|c|c|}
\hline Month & $\begin{array}{l}\text { Manama } \\
(\mathrm{ml} / \mathrm{hr})\end{array}$ & $\begin{array}{ll}\text { Av. Temp. } \\
\left({ }^{\circ} \mathrm{C}\right)\end{array}$ & $\begin{array}{l}\text { Av. RH } \\
\%\end{array}$ & $\begin{array}{l}\text { Av. AH } \\
g m / m^{3}\end{array}$ & $\begin{array}{l}\text { Dew Point } \\
\left({ }^{\circ} \mathrm{C}\right)\end{array}$ \\
\hline Jul. & 394.88 & 36.20 & 50.70 & 31.11 & 23.20 \\
\hline Aug.t & 350.27 & 36.69 & 52.69 & 34.58 & 24.46 \\
\hline Sep. & 328.50 & 33.54 & 59.54 & 42.99 & 24.31 \\
\hline Oct. & 317.20 & 29.25 & 52.75 & 27.64 & 17.25 \\
\hline Nov. & 337.82 & 25.00 & 64.85 & 40.27 & 17.69 \\
\hline Dec. & 314.36 & 21.08 & 70.58 & 43.09 & 15.91 \\
\hline Month & Barbar $(\mathrm{ml} / \mathrm{hr})$ & $\begin{array}{ll}\text { Av. } & \text { Temp. } \\
\left({ }^{\circ} \mathrm{C}\right) & \\
\end{array}$ & $\begin{array}{l}\text { Av. RH } \\
\%\end{array}$ & $\begin{array}{ll}\begin{array}{l}\text { Av. } \\
\text { gm/ } \mathbf{m}^{3}\end{array} & \text { AH } \\
\end{array}$ & $\begin{array}{ll}\text { Dew Point } \\
\left({ }^{\circ} \mathrm{C}\right)\end{array}$ \\
\hline Jul. & 397.31 & 36.18 & 49.90 & 29.96 & 23.10 \\
\hline Aug.t & 451.46 & 36.77 & 52.46 & 34.29 & 24.46 \\
\hline Sep. & 456.92 & 33.54 & 59.54 & 42.99 & 24.31 \\
\hline Oct. & 380.55 & 29.25 & 52.75 & 27.64 & 17.25 \\
\hline Nov. & 332.10 & 25.00 & 64.85 & 40.27 & 17.69 \\
\hline Dec. & 401.64 & 21.08 & 70.58 & 43.09 & 15.91 \\
\hline Month & Hidd (ml/hr) & $\begin{array}{ll}\text { Av. } & \text { Temp } \\
\left({ }^{\circ} \mathrm{C}\right) & \\
\end{array}$ & $\begin{array}{l}\text { Av. RH } \\
\%\end{array}$ & $\begin{array}{l}\text { Av. AH } \\
g m / m^{3}\end{array}$ & $\begin{array}{ll}\text { Dew Point } \\
\left({ }^{\circ} \mathrm{C}\right)\end{array}$ \\
\hline Jul. & 407.78 & 35.80 & 51.20 & 31.49 & 22.89 \\
\hline Aug.t & 427.73 & 37.00 & 51.00 & 32.25 & 24.25 \\
\hline Sep. & 390.00 & 33.62 & 59.54 & 43.09 & 24.38 \\
\hline Oct. & 400.00 & 29.00 & 56.43 & 32.39 & 18.36 \\
\hline Nov. & 315.82 & 25.08 & 61.67 & 35.28 & 23.30 \\
\hline
\end{tabular}




\begin{tabular}{|c|c|c|c|c|c|}
\hline Dec. & 314.58 & 21.67 & 72.25 & 47.38 & 16.42 \\
\hline Month & Sanad $(\mathrm{ml} / \mathrm{hr})$ & $\begin{array}{ll}\text { Av. } & \text { Temp } \\
\left({ }^{\circ} \mathrm{C}\right) & \end{array}$ & $\begin{array}{l}\text { Av. RH } \\
\%\end{array}$ & $\begin{array}{l}\text { Av. AH } \\
\text { gm/ } / \mathbf{m}^{3}\end{array}$ & $\begin{array}{l}\text { Dew Point } \\
\left({ }^{\circ} \mathrm{C}\right)\end{array}$ \\
\hline Jul. & 371.11 & 35.82 & 52.18 & 32.98 & 23.73 \\
\hline Aug.t & 327.92 & 36.64 & 53.71 & 36.19 & 24.79 \\
\hline Sep. & 317.92 & 33.83 & 59.58 & 43.45 & 24.50 \\
\hline Oct. & 311.36 & 29.15 & 55.31 & 30.96 & 17.77 \\
\hline Nov. & 332.31 & 24.92 & 63.25 & 37.50 & 14.75 \\
\hline Dec. & 303.62 & 20.82 & 70.18 & 41.86 & 14.70 \\
\hline Month & $\begin{array}{l}\text { Salamabad } \\
(\mathrm{ml} / \mathrm{hr})\end{array}$ & $\begin{array}{ll}\text { Av. } & \text { Temp } \\
\left({ }^{\circ} \mathrm{C}\right) & \\
\end{array}$ & $\begin{array}{l}\text { Av. RH } \\
\%\end{array}$ & $\begin{array}{l}\begin{array}{l}\text { Av. } \\
\text { gm/m } / \mathbf{m}^{3}\end{array} \\
\text { AH }\end{array}$ & $\begin{array}{l}\text { Dew Point } \\
\left({ }^{\circ} \mathrm{C}\right)\end{array}$ \\
\hline Jul. & 336.25 & 35.82 & 52.18 & 32.98 & 23.73 \\
\hline Aug.t & 323.55 & 36.64 & 53.71 & 36.19 & 24.79 \\
\hline Sep. & 292.92 & 33.83 & 59.00 & 42.35 & 17.33 \\
\hline Oct. & 271.00 & 29.42 & 53.00 & 28.12 & 17.33 \\
\hline Nov. & 296.08 & 25.08 & 60.58 & 33.65 & 14.33 \\
\hline Dec. & 305.67 & 20.82 & 53.71 & 20.56 & 14.70 \\
\hline Month & $\begin{array}{l}\text { HamadTown } \\
\text { (ml/hr) }\end{array}$ & $\begin{array}{ll}\text { Av. } & \text { Temp } \\
\left({ }^{\circ} \mathrm{C}\right) & \end{array}$ & $\begin{array}{l}\text { Ave. RH } \\
\%\end{array}$ & $\begin{array}{l}\begin{array}{l}\text { Av. AH } \\
\text { gm/ } \mathbf{m}^{3}\end{array}\end{array}$ & $\begin{array}{l}\text { Dew Point } \\
\left({ }^{\circ} \mathrm{C}\right)\end{array}$ \\
\hline Jul. & 291.94 & 35.75 & 52.92 & 34.05 & 22.40 \\
\hline Aug.t & 238.89 & 36.62 & 53.15 & 35.25 & 25.43 \\
\hline Sep. & 207.00 & 33.54 & 59.54 & 42.99 & 24.08 \\
\hline Oct. & 236.89 & 29.17 & 54.67 & 30.08 & 17.58 \\
\hline Nov. & 197.29 & 25.23 & 63.54 & 38.45 & 15.46 \\
\hline Dec. & 263.55 & 20.22 & 69.56 & 39.63 & 14.33 \\
\hline
\end{tabular}

This data is presented in this paper and is offered to other researchers along with more data as the project progresses. After the completion of this project, the full 12month data with all details will be made available to other researchers upon contacting the first author with their request.

\section{4- Conclusions}

The following are remarks that could be drawn from the aforementioned work:

- In this paper the authors presented an ongoing project that is being conducted at the civil engineering department of the University of Bahrain. At the time of writing this article, the research is in its midway and currently, some results have been attained but many others are in the making. 
- Preliminary chemical analysis of the harvested indicated that the harvested water, which was kept raw without any filtration, was close to pure. But more tests are are needed to verify this finding. Actually, 6 samples from each collection site were sent to the official Bahrain government water quality and ministry of health labs for a comprehensive list of tests that covers all of the world health organization requirements for drinking water.

- The efficiency of the utilized dehumidifier is very low. This efficiency is expected, since the surface are of the condenser inside the used device is only $15 \mathrm{~cm} \times 15 \mathrm{~cm}$. Furthermore, the utilized dehumidifier is rated for indoor use and in this experiment it was stretched to its limits by being operated in the outdoors with full exposure to the climatic elements, especially the dust in sandstorm days.

- Results show that locations that are close to the shores have higher potential to harvest more water from atmospheric humidity. Results have also shown that absolute humidity and not relative humidity is the factor with direct correlation to the amount of harvestable air humidity.

- Preliminary cost analysis of the harvested water based on a 5\%-efficient harvesting device is very promising, yet with the advent of more data in the coming few weeks/months more conclusive findings on a more solid ground can be reached.

- It is the belief of the authors of this paper that harvesting water from air humidity, especially in a geographical setup like that of the kingdom of Bahrain, is very promising for many reasons. Among those are: its simple design, substantially, smaller size, area and operation cost than desalination plants, and savings in installation costs since water is drawn from air without the need for of elaborate piping system.

- Finally, this study can be considered as a door opener to more comprehensive studies about water harvesting of atmospheric humidity in the Kingdom of Bahrain in which, a full-scale production system is utilized. 


\section{Acknowledgement:}

The authors would like to express their sincere thanks for the all the nice people, who supported this budget-less project. Thanks are extended to H.E. Sh. Nawaf AlKhalifa and his wonderful team at Electricity and Water Authority (EWA) for their support and help in performing water quality tests on EWA labs. Thanks are also extended to the Dean of Engineering, Dr. Fuad Al-Ansari, for his support of this project and to all of whom giving us any direct or indirect help. 


\section{References}

1. Abualhamayel, H. and Gandhidasan, P. "A Method of Obtaining Fresh Water from the Humid Atmosphere,” Elsevier Desalination Journal, Vol. 113, November 1997, pp. 51-63.

2. Ahrens D., "Essentials of Meteorology: An Invitation to the Atmosphere," 7th edition, Cengage Learning Pulishing, Boston, MA, USA, January 2014.

3. Alekseev, V., Rustamo, N., Ivanov, V. and Dubovskaya V. "Experimental Study of Overland Moisture Condensation," Doklady Earth Sciences, Vol. 393, No. 8, August 2003, pp. 1156-1159.

4. Alnaser, W. and Barakat, A. "Use of Condensed Water Vapor from the Atmosphere for Irrigation in Bahrain," Elsevier Applied Energy Journal, Vol. 65, No. 1, January 2000, pp. 3-18.

5. Alipour, V., Mahvi, A. and Rezaei, L. "Water Condensate Management of Atmosphere Humidity in Bandar Abbas, Iran," Proceedings of WSEAS 9th International Conference on Energy, Environment, Ecosystems and Sustainable Development (EEESD '13), Lemesos, Cyprus, March 2013, pp. 279-284.

6. Atta, R. "Solar Water Condensation Using Thermoelectric Coolers," International Journal of Water Resources and Arid Environments, vol. 1, No. 2, April 2011, pp. 142-145.

7. Alayli, Y., Hadji, N. and Leblond, J. "A New Process for the Extraction of Water from Air,” Elsevier Desalination, Vol. 67, December 1987, pp. 227-229.

8. Bergmair, D. "Design of a System for Humidity Harvesting Using Water Vapor Selective Membranes," A Ph.D. Thesis submitted to the Mechanical Engineering Department of the Eindhoven University of Technology, Austria, 2015.

9. Beysens, D., and Milimouk, I. "The Case for Alternative Fresh Water Sources," Translated by T. Fuller from "Pour les Ressources Alternatives en eau" Sécheresse, vol. 11, No. 4, December 2000.

10. Bolonkin, A. "Extraction of Freshwater and Energy from Atmosphere," arxiv:0704.2571.

11. Bolton, D. "The Computation of Equivalent Potential Temperature," Monthly Weather Review. Vol.108, No. 7, July 1980, pp. 1046-1053.

12. Davtalab, R. and Salamat A. "Water Harvesting from Fog and air Humidity in the Warm and Coastal Regions in the South of Iran," ICID 21 ${ }^{\text {st }}$, International Congress on Irrigation and Drainage, 15-23 October 2011, Tehran, Iran.

13. Directorate of Meteorology, Civil Aviation, Kingdom of Bahrain, verbal communication.

14. Eindhoven University of Technology. "Cotton with special coating collects water from fogs in desert," Science Daily, January 2013. 
15. Esfandiarnejad, A., Ahangar, R., Kamalian, U. and Sangchouli T., "Feasibility Studies for Water Harvesting from Fog and Atmospheric Moisture in Hormozgan Coastal Zone (south of Iran)" Proceedings of the $5^{\text {th }}$ International Conference on Fog, Fog Collection and Dew, Münster, Germany, July 2010 .

16. Gaware, N., Nadar, M. and Vedpathak M. "Harvesting of Water from Air Using Helical Coil," International Journal of Engineering Sciences \& Research Technology, Vol. 4, No. 2, Feb. 2015, pp. 178-182.

17. Grand View Research "Atmospheric Water Generator Market Analysis, Market Size, Application Analysis, Regional Outlook, Competitive Strategies And Forecasts, 2015 To 2022” A Report by Grand View Research, Inc. San Francisco, California, U.S.A,

18. Hamed, A., Aly, A and Zeidan E. "Application of Solar Energy for Recovery of Water from Atmospheric Air in Climatic Zones of Saudi Arabia," SCRIP Open Access Natural Resources Journal, Vol. 2, No. 1, March 2011, pp. 8-17,

19. Hamed, A., Kabeel, A., Zeidan, E. and Aly, A. "A Technical Review on the Extraction of Water from Atmospheric Air in Arid Zones," JP Journal of Heat and Mass Transfer, Vol. 4, No. 3, 2010, pp 213-228.

20. Kumar ,M. and Yadav, A. "Experimental Investigation of Solar Powered Water Production from Atmospheric Air by Using Composite Desiccant Material " $\mathrm{CaCl} 2 / \mathrm{saw}$ Wood"," Elsevier Desalination Journal, Vol. 367, No. 1, July 2015, pp. 216-222.

21. Lindblom, J. and Nordell, B. "Water Production by Underground Condensation of Humid Air,” Elsevier Desalination Journal, Vol. 189, March 2006, pp. 248-260.

22. Nandy, A., Saha, S., Ganguly, S. and Chattopadhyay S." A Project on Atmospheric Water Generator with the Concept of Peltier Effect," International Journal of Advanced Computer Research, Vol. 4, No 2, June 2014, pp 481-486.

23. Ngaina J, Muthama J., Opere A., Ininda J., Ng'etich C., Ongoma V. and Mutai B. "Potential of Harvesting Atmospheric Water over Urban Cities in Kenya," International Journal of Physical Sciences, Vol. 2, No. 5, May 2014, pp. 69-75.

24. Pauli, G. "The Blue Economy: 10 Years, 100 Innovations, 100 Million Jobs," Paradigm Publications, New Mexico, U.S.A., 2010, ISBN 9780912111902

25. Reznikov, M., Salazar, M. and Lopez, M. "Electrically Enhanced Harvesting of Water Vapor from the Air" Proceedings of The 2015 Electrostatics Society of America (ESA) Annual Meeting on Electrostatics, Paloma, CA, U.S.A. June 2015, pp. 1-11.

26. World Health Organization: Guidelines for drinking water quality, Incorporating First Addendum, Recommendations, 2006.

27. Yang, H., Zhu, H., Hendrix, M., Lousberg, N., de With, G., Esteves, C. and Xin J. "Temperature-Triggered Collection and Release of Water from Fogs by a Sponge-Like Cotton Fabric," Advanced Materials, 2013; DOI: 10.1002/adma.201204278 